\title{
A writer's guide to education scholarship: Qualitative education scholarship (part 2)
}

\author{
Teresa M. Chan, HBSc, BEd, MD, MHPE*; Daniel K. Ting, MD ${ }^{\dagger}$; Andrew Koch Hall, MD, MMEd ${ }^{\ddagger}$; \\ Aleisha Murnaghan, BSc, MD, MHPE ${ }^{\S}$; Brent Thoma, MD/MA, MSc ; Jill McEwen, MD**; \\ Lalena M. Yarris, MD, $\mathrm{MCR}^{\dagger \dagger}$
}

\section{ABSTRACT}

Objective: Education scholarship can be conducted using a variety of methods, from quantitative experiments to qualitative studies. Qualitative methods are less commonly used in emergency medicine (EM) education research but are wellsuited to explore complex educational problems and generate hypotheses. We aimed to review the literature to provide resources to guide educators who wish to conduct qualitative research in EM education.

Methods: We conducted a scoping review to outline: 1) a list of journals that regularly publish qualitative educational papers; 2) an aggregate set of quality markers for qualitative educational research and scholarship; and 3) a list of quality checklists for qualitative educational research and scholarship. Results: We found nine journals that have published more than one qualitative educational research paper in EM. From the literature, we identified 39 quality markers that were grouped into 10 themes: Initial Grounding Work (preparation, background); Goals, Problem Statement, or Question; Methods (general considerations); Sampling Techniques; Data Collection Techniques; Data Interpretation and Theory Generation; Measures to Optimize Rigour and Trustworthiness; Relevance to the Field; Evidence of Reflective Practice; Dissemination and Reporting. Lastly, five quality checklists were found for guiding educators in reporting their qualitative work.

Conclusion: Many problems that EM educators face are wellsuited to exploration using qualitative methods. The results of our scoping review provide publication venues, quality indicators, and checklists that may be useful to EM educators embarking on qualitative projects.

\section{RÉSUMÉ}

Introduction: Les travaux de recherche en enseignement peuvent être menés selon différentes méthodes, depuis les études expérimentales quantitatives jusqu'aux études qualitatives. Les méthodes qualitatives sont moins utilisées que les autres dans la recherche en enseignement de la médecine d'urgence (MU), mais elles conviennent très bien à l'étude de problèmes complexes en enseignement et à l'émission d'hypothèses. Aussi avons-nous procédé à un examen de la documentation afin de proposer des ressources aux éducateurs qui désirent réaliser de la recherche qualitative en enseignement de la MU.

Méthode: Nous avons effectué un examen de la portée afin : 1) de dresser une liste de revues qui publient souvent des travaux de recherche qualitative en enseignement; 2) d'établir un ensemble de marqueurs de qualité s'appliquant à la recherche qualitative en enseignement et aux travaux scientifiques; 3 ) de relever des listes de vérification de la qualité s'appliquant à la recherche qualitative en enseignement et aux travaux scientifiques.

Résultats: La recherche a permis de recenser neuf revues qui avaient publié plus d'un travail de recherche qualitative en enseignement de la MU. II s'est dégagé de l'examen de la documentation 39 marqueurs de qualité, groupés en 10 thèmes : les travaux préliminaires (les préparatifs, le contexte); le but, l'énoncé du problème ou la question; la méthode (généralités); la technique d'échantillonnage; la technique de collecte de données; l'interprétation des données et l'élaboration de théories; les mesures d'amélioration de la rigueur et de la véracité; la pertinence de la recherche dans le domaine; les signes de la pratique réflexive; la diffusion et l'établissement de rapports. Enfin se sont dégagées de la recension cinq listes de vérification de la qualité susceptibles d'aider les éducateurs dans l'établissement de rapports sur leurs travaux de recherche qualitative. Discussion: De nombreux problèmes auxquels font face les éducateurs en $\mathrm{MU}$ se prêtent bien à la recherche menée à l'aide de méthodes qualitatives. L'examen de la portée a permis de relever différents éditeurs, des indicateurs de qualité et des listes de vérification susceptibles de guider les éducateurs en MU qui désirent faire de la recherche qualitative.

Keywords: qualitative research, education scholarship, academic writing

From the *Division of Emergency Medicine, Department of Medicine, McMaster University, Hamilton, ON; †Department of Emergency Medicine, University of British Columbia, Kelowna, BC; $¥$ Department of Emergency Medicine, Queen’s University, Kingston, ON; §Department of Emergency Medicine, University of Ottawa, Ottawa, ON; IDepartment of Emergency Medicine, Department of Medicine, University of Saskatchewan, Saskatoon, SK; **Department of Emergency Medicine, University of British Columbia, Vancouver, BC; and †tDepartment of Emergency Medicine, Oregon Health \& Science University, Portland, OR.

Correspondence to: Dr. Teresa M. Chan, Division of Emergency Medicine, Department of Medicine, McMaster University, 1280 Main Street West, Hamilton, ON L8S 4L8; Email: teresa.chan@medportal.ca 


\section{INTRODUCTION}

\section{Background}

Medical education is a sizeable field that encompasses many research paradigms. One of the exciting areas of growth in the past 30 years has been the surge of work rooted in qualitative methods. Qualitative approaches stem from social science research practices. Rather than quantifying, predicting, or modeling outcomes, they aim to create a deep understanding of a situation or phenomenon. ${ }^{1-3}$

These methods have been largely underused in emergency medicine (EM) medical education circles, but they have the opportunity of making a great impact on educational practice. Qualitative studies delve into the richness of complex phenomena, seeking to answer the "whys" and "hows." These pursuits contrast with quantitative studies, which aim to answer focused questions ("Does this intervention work?", "How much does this change that?"). ${ }^{4}$ In the past decade, there has been a growing interest in applying the qualitative paradigms to answer questions in the larger field of medical education, ${ }^{5-7}$ but there has been less uptake regarding qualitative methods in education papers within our specialty.

Despite this, a burgeoning respect for the use of qualitative approaches has developed in EM. In 2007, the Society of Academic Emergency Medicine (SAEM) consensus conference on knowledge translation affirmed that qualitative research has an important role for advancing the cause of translating knowledge to the bedside. ${ }^{8}$ Although this statement emerged from a broader context than EM education, it demonstrated an appreciation of the role of qualitative work in understanding the contextual nuances of implementing educational programs and inciting behavioural change. Since 2013, a group within the Academic Emergency Medicine journal has highlighted qualitative studies in their annual review of EM education papers. ${ }^{9,10}$

Many qualitative methods draw from the social sciences, each method bringing with it the perspective of its originating field. Table 1 describes some of the commonly applied qualitative methods in education research and includes exemplar papers that fit within each paradigm.

Qualitative research often receives critique, especially from reviewers unfamiliar with these methods, regarding perceptions of excessive bias or anecdote, vague or heterogeneous methodology, and absence of external validity or rigour. ${ }^{17}$ Fortunately, useful guides exist to help readers and reviewers better understand qualitative work such as the User's Guide series from The fournal of the American Medical Association. ${ }^{18,19}$ As these guides outline, qualitative research has its own set of rules that govern rigour, and threats to validity that can be addressed and minimized with thoughtful study design and execution.

This paper presents the results of a scoping review that aims to identify literature-based resources that EM educators may use to design, implement, and author qualitative research studies. Our literature search focused on a key primary question: what are the quality markers for qualitative educational research as described in the literature? We also explored the literature from our search to answer the following three secondary questions: 1 ) How frequently are qualitative papers published in EM journals? 2) Which journals regularly publish qualitative educational papers? 3) What are commonly used quality checklists for qualitative educational research?

\section{METHODS}

\section{Literature search to identify relevant studies}

We performed a scoping review using the approach described by Arskey and O'Malley. ${ }^{20}$ We conducted an initial search using the MEDLINE database from the National Library of Medicine as well as the ERIC database in December 2015. Our search was limited to human and English language papers using "and/or" combinations of variations of the following keywords: qualitative, emergency medicine, qualitative methods, and medical education. An adjunctive search was undertaken via Google Scholar. Google Scholar has been previously noted in the literature as an alternative search method that can replace the use of other databases for review papers. ${ }^{21}$ In this instance, we used it to supplement our other database searches. ${ }^{22,23}$ The keywords medical education, emergency medicine, and qualitative were used. We did not specify a time period for publications and accessed all literature available in the MEDLINE and ERIC databases from their beginning date. A master list was created of all articles resulting from the three searches, duplicates were excluded, and a manual search of the references of final papers was conducted to identify additional papers to add to the master list. 
Table 1. Key features of various qualitative methods

\begin{tabular}{|c|c|c|c|}
\hline Method & When you use this technique & Exemplar paper & "How to" papers \\
\hline Grounded theory $y^{2,11-13}$ & $\begin{array}{l}\text { Generates theory in areas where } \\
\text { little is known about the topic. } \\
\text { Inductive analysis of the data is } \\
\text { used to produce hypotheses, } \\
\text { which are iteratively tested } \\
\text { through further data collection. }\end{array}$ & $\begin{array}{l}\text { Kennedy TJ, Lingard L, Baker GR, et al. } \\
\text { Clinical oversight: conceptualizing the } \\
\text { relationship between supervision and } \\
\text { safety. J Gen Intern Med 2007; } \\
\text { 22(8):1080-5. }\end{array}$ & $\begin{array}{l}\text { Kennedy TJ, Lingard LA. Making } \\
\text { sense of grounded theory in } \\
\text { medical education. Med Educ } \\
\text { 2006;40(2):101-8. } \\
\text { Watling CJ, Lingard L. Grounded } \\
\text { theory in medical education } \\
\text { research: AMEE Guide No. } 70 . \\
\text { Med Teach 2012;34(10):850-61. }\end{array}$ \\
\hline $\begin{array}{l}\text { Ethnography }{ }^{2,11-13} \\
\text { (including } \\
\text { autoethnography }{ }^{14} \text { ) }\end{array}$ & $\begin{array}{l}\text { Focuses on culture and } \\
\text { understanding of how } \\
\text { individuals interact within } \\
\text { that culture. Observation is } \\
\text { the key method of collecting } \\
\text { data. }\end{array}$ & $\begin{array}{l}\text { Nugus } \mathrm{P} \text {, Holdgate } \mathrm{A} \text {, Fry } \mathrm{M} \text {, et al. Work } \\
\text { pressure and patient flow } \\
\text { management in the emergency } \\
\text { department: findings from an } \\
\text { ethnographic study. Acad Emerg } \\
\text { Med 2011;18(10):1045-52. }\end{array}$ & $\begin{array}{l}\text { Goodson L, Vassar M. An overview } \\
\text { of ethnography in healthcare and } \\
\text { medical education research. } \\
\text { J Educ Eval Health Prof 2011;8:4. } \\
\text { Farrell L, Bourgeois-Law G, } \\
\text { Regehr G, et al. Autoethnography: } \\
\text { introducing 'I' into medical } \\
\text { education research. Med Educ } \\
\text { 2015;49(10):974-82. }\end{array}$ \\
\hline Phenomenology $2,11-13$ & $\begin{array}{l}\text { Explores a specific phenomenon } \\
\text { and how it is experienced by } \\
\text { participants (known as the } \\
\text { "lived experience"). }\end{array}$ & $\begin{array}{l}\text { Babaria P, Abedin S, Nunez-Smith M. } \\
\text { The effect of gender on the clinical } \\
\text { clerkship experiences of female } \\
\text { medical students: results from a } \\
\text { qualitative study. Acad Med 2009; } \\
\text { 84(7):859-66. }\end{array}$ & $\begin{array}{l}\text { Stenfors-Hayes T, Hult } \mathrm{H} \text {, } \\
\text { Dahlgren MA. A pheno- } \\
\text { menographic approach to research } \\
\text { in medical education. Med Educ } \\
\text { 2013;47(3):261-70. }\end{array}$ \\
\hline Action research 2,11 & $\begin{array}{l}\text { Uses the research process to } \\
\text { bring about a change in } \\
\text { practice. Alternates between } \\
\text { changes in a system and } \\
\text { evaluation of that system. }\end{array}$ & $\begin{array}{l}\text { Eisenberg EM, Baglia J, Pynes JE. } \\
\text { Transforming emergency medicine } \\
\text { through narrative: qualitative action } \\
\text { research at a community hospital. } \\
\text { Health Commun 2006;19(3):197-208. }\end{array}$ & $\begin{array}{l}\text { Genn JM, Harden RM. What is } \\
\text { medical education here really like? } \\
\text { Suggestions for action research } \\
\text { studies of climates of medical } \\
\text { education environments. Med } \\
\text { Teach 1986;8(2):111-24. }\end{array}$ \\
\hline Narrative analysis $^{12}$ & $\begin{array}{l}\text { Examines how individuals use } \\
\text { stories to interpret } \\
\text { experiences. }\end{array}$ & $\begin{array}{l}\text { Apker J, Mallak LA, Gibson SC. } \\
\text { Communicating in the "gray zone": } \\
\text { perceptions about emergency } \\
\text { physician hospitalist handoffs and } \\
\text { patient safety. Acad Emerg Med } \\
\text { 2007;14(10):884-94. }\end{array}$ & $\begin{array}{l}\text { Bleakley A. Stories as data, data as } \\
\text { stories: making sense of narrative } \\
\text { inquiry in clinical education. Med } \\
\text { Educ 2005;39(5):534-40. }\end{array}$ \\
\hline Mixed methods ${ }^{13,16}$ & $\begin{array}{l}\text { Strategically combines } \\
\text { techniques from both } \\
\text { quantitative and qualitative } \\
\text { traditions to answer questions } \\
\text { around a specific situation and/ } \\
\text { or phenomenon. Typically } \\
\text { suggested when studying new } \\
\text { areas or complex systems/ } \\
\text { programs. }\end{array}$ & $\begin{array}{l}\text { Papp KK, Stoller EP, Sage } \mathrm{P} \text {, et al. The } \\
\text { effects of sleep loss and fatigue on } \\
\text { resident-physicians: a multi- } \\
\text { institutional, mixed-method study. } \\
\text { Acad Med 2004;79(5):394-406. }\end{array}$ & $\begin{array}{l}\text { Schifferdecker KE, Reed VA. Using } \\
\text { mixed methods research in } \\
\text { medical education: basic } \\
\text { guidelines for researchers. Med } \\
\text { Educ 2009;43(7):637-44. }\end{array}$ \\
\hline Case studies $^{2}$ & $\begin{array}{l}\text { These allow in-depth analysis of } \\
\text { a single particular case. }\end{array}$ & $\begin{array}{l}\text { Gagnon MP, Duplantie J, Fortin JP, } \\
\text { et al. Exploring the effects of } \\
\text { telehealth on medical human } \\
\text { resources supply: a qualitative case } \\
\text { study in remote regions. BMC Health } \\
\text { Serv Res 2007;7:6. }\end{array}$ & $\begin{array}{l}\text { Rowley J. Using case studies in } \\
\text { research. Management Research } \\
\text { News 2002;25(1):16-27. (Not from } \\
\text { medical education literature) }\end{array}$ \\
\hline
\end{tabular}




\section{Selection of articles for the scoping analysis}

Two investigators (TMC, DKT) performed the literature search and reviewed titles for relevancy. For the scoping analysis, we included all papers that provided guidance to authors wishing to conduct, report, or write qualitative studies or educational scholarship. We did not limit the inclusion of articles to EM literature, and instead looked more broadly into the general medical and medical education literature. We excluded papers that merely used qualitative methods. These excluded papers were kept and used for the frequency analysis, which is mentioned later in our methods. To ensure interrater consistency, the first 100 titles obtained from the MEDLINE search were reviewed together to determine consensus on which types of titles were to be included or excluded.

\section{Charting and analysis of the quality markers}

Our primary aim was to develop a literature-based set of quality markers for qualitative research, which we defined as items that were written as advice to authors of qualitative research that were not already within known qualitative scoring systems. To identify candidate quality markers, a single investigator (TMC) read the full-text articles remaining from the literature search after inclusion criteria were applied. Quality markers mentioned in the text, diagrams, figures, or tables were extracted into a master list. ${ }^{24}$ These quality markers were combined into one single master list, and then a close analysis was performed by a single investigator (TMC) to group and reduce this list in the manner described by Arskey and O'Malley into its final form. ${ }^{20}$ To enhance the rigour of this analysis, two investigators (DKT, JM) surveyed the analysis audit trail (i.e., the analysis documents) after reviewing the 11 full-text articles.

\section{Qualitative publishing frequency and journal identification}

To identify journals that publish qualitative research relevant to EM education, we determined the overlap of qualitative medical education research papers and qualitative research in EM. This frequency analysis was done with medical education papers using qualitative methods that were found in our initial literature search, but which were excluded from the scoping analysis.
After merging the results of the three database searches and excluding duplicates, the citations were manually sorted using the Mendeley reference software into mutually inclusive categories of "qualitative research," "medical education," "emergency medicine," or combinations of these two groupings (i.e., "qualitative research and emergency medicine" or "medical education and emergency medicine"). When the article title resulted in ambiguous characterization, the abstract or full-text was reviewed. We then generated a list of journals that had published at least one qualitative research articles relevant to EM medical education. From this list, we also produced a subset of journals with at least two qualifying publications.

\section{Quality checklist identification}

The manuscripts reviewed in the full-text phase were read in total by two authors (TMC, JM), and papers with relevant checklists were extracted.

\section{RESULTS}

Citations totalling 1,337 were obtained from our search strategy. These papers were reviewed for duplication and then subjected to the inclusion and exclusion criteria. Figure 1 depicts how papers were removed at various stages to arrive at the final set of full-text papers used for the scoping analysis $(n=11)$.

\section{Quality markers for qualitative studies}

We reviewed 62 papers in full-text form for quality markers. Of these, 11 papers had specific items that could be extracted for the close analysis. Appendix A lists the 11 papers. Table 2 contains the results of our thematic analysis of quality markers in qualitative research, based on the close analysis of relevant papers from our literature review.

\section{Quantifying the qualitative publishing rates}

Our literature search revealed a separate set of 387 citations of EM qualitative research papers and 314 of EM medical education papers; 59 citations overlapped between these two categories, which represent qualitative education research relevant to EM (Figure 2). 


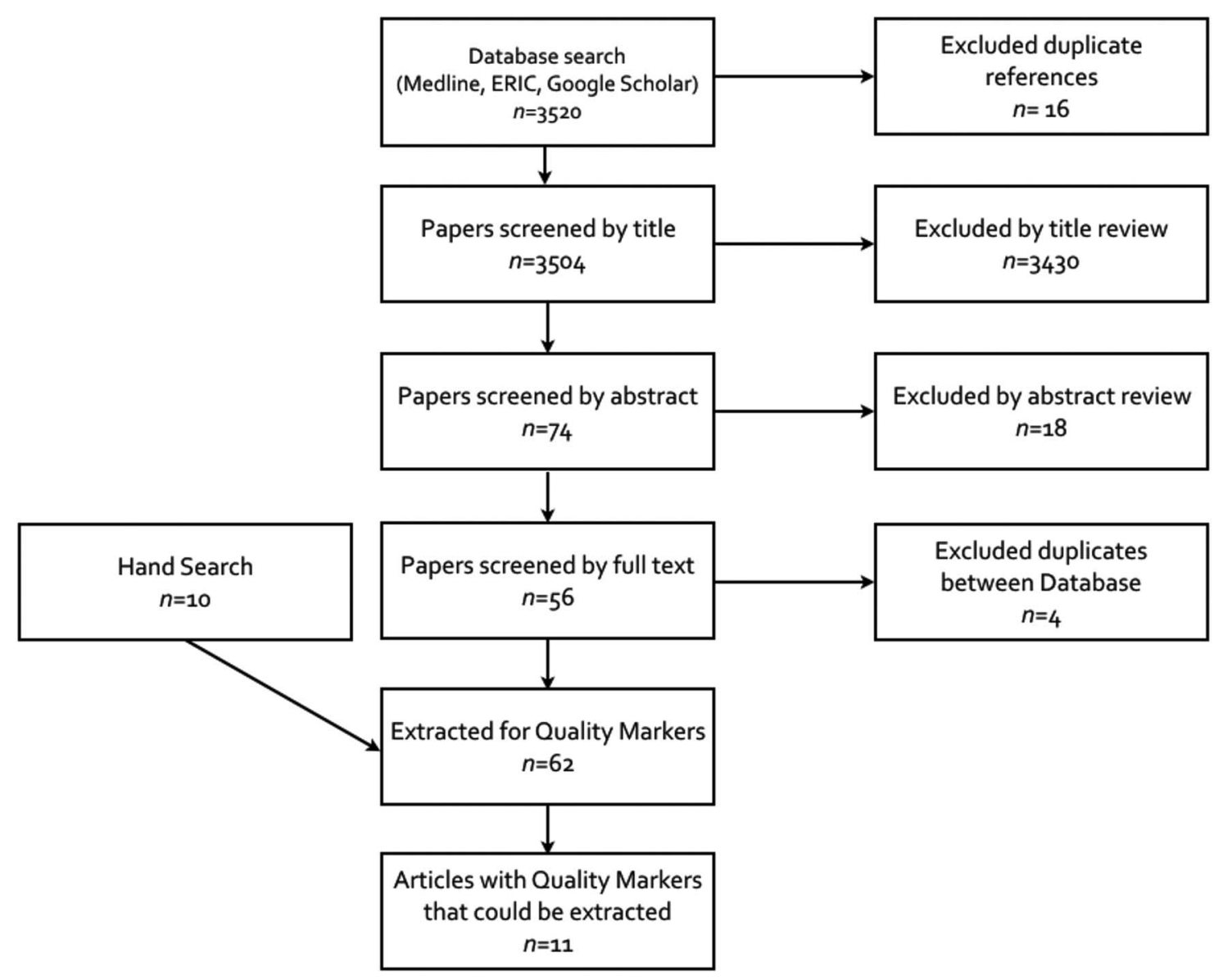

Figure 1. Flow diagram for literature review.

\section{Checklists for quality}

Our search identified five papers that had developed and reported checklists or scoring metrics useful for evaluating qualitative research (Table 3). The fifth paper by Sullivan et al. reported features useful for determining quality and value of both qualitative and quantitative research. These checklists would all be useful for consultation when designing a qualitative study, writing and editing manuscripts, performing editorial review of manuscripts, and performing critical appraisal of a qualitative paper.

We found 33 journals that publish EM qualitative research in medical education (Appendix B). Of these, 9 journals had at least two qualifying papers, as listed in Table 4.

\section{DISCUSSION}

Qualitative methods have the potential to provide us with new insight and clarity into the educational problems and dilemmas that we face within our specialty. As illustrated in Table 1, there are wide ranges of research methods that can be used to answer questions within the field of medical education. Furthermore, as evidenced by Table 4 and Appendix B, there are an increasing number of medical journals amenable to publishing rigorous qualitative work in EM and medical education. Figure 2 depicts that approximately $18.9 \%$ (59/314) of the EM education papers in our literature search were qualitative in nature. Similarly, we found that a slightly smaller proportion of EM qualitative papers $(15.2 \%$ [59/397]) were educational papers. Taken together, our findings suggest that, despite a growing interest, only a minority of studies use qualitative methods. Given that many educational problems involve emerging theory or little understood phenomenon, we propose that qualitative methods are underused in EM education.

Interestingly, our thematic analysis of the 11 papers with advice and tips for writing qualitative methods yielded disparate items from those addressed in the 


\section{Table 2. Markers of quality in qualitative education research studies}

\begin{tabular}{|c|c|}
\hline Category & Item \\
\hline $\begin{array}{l}\text { Initial grounding work (preparation, } \\
\text { background) }\end{array}$ & $\begin{array}{l}\text { - Adequate preparation }{ }^{25} \text { that includes a thoughtful, focused, up-to-date review of the literature } \\
\text { (unless technique requires deliberate distancing from prior experience). } \\
\text { - A conceptual linkage to existing theory. }{ }^{27} \\
\text { - Declaration and report of one's theoretical paradigms and values, }{ }^{28} \text { or position. }{ }^{28}\end{array}$ \\
\hline $\begin{array}{l}\text { Goals, problem statement, or } \\
\text { question }\end{array}$ & $\begin{array}{l}\text { - Clear statement of the research goals }{ }^{25-27,11} \text { and research questions }{ }^{27,29} \text { - point out that as the study is } \\
\text { inductive, there are no hypotheses. }{ }^{11} \\
\text { - The problem is important, timely, relevant, critical, and prevalent. }{ }^{26} \\
\text { - Clear articulation of the research questions }{ }^{29} \text { or goals. }{ }^{25}\end{array}$ \\
\hline $\begin{array}{l}\text { Methods } \\
\text { (general) }\end{array}$ & $\begin{array}{l}\text { - Appropriate methods }{ }^{25} \text { are justified }{ }^{27} \text { (i.e., why is a qualitative approach the best option to answer your } \\
\text { question } ?^{27} \text { Why was the particular qualitative design chosen }{ }^{27} \text { ). } \\
\text { - Clear methodology }{ }^{28} \text { (i.e., clearly describe the sampling, data collection, data analysis/interpretation, } \\
\text { and methods for establishing rigour). } \\
\text { - Explanation that, as the approach is inductive, the methods, tools, and approaches may have changed } \\
\text { as the study progressed. }{ }^{11} \\
\text { - Report ethical approval }{ }^{27} \text { or waiver from an appropriate institution. }\end{array}$ \\
\hline Sampling technique & $\begin{array}{l}\text { - Use of a sampling plan }{ }^{29} \text { that ensures participants are relevant to the research question or problem } \\
\text { statement }{ }^{18} \text { and that their selection is well reasoned, }{ }^{18} \text { because qualitative studies are more likely to } \\
\text { focus on a social world or phenomenon rather than a specific population. }{ }^{11} \\
\text { - Sampling should be guided and selective. }{ }^{30} \text { Theoretically driven, }{ }^{11} \text { purposive/purposeful sampling, }{ }^{30} \text { or } \\
\text { snowball sampling }{ }^{11,30} \text { may be better than random or convenience sampling. } \\
\text { - Sample size sufficiently large }{ }^{26} \text { but driven by saturation }{ }^{11} \text { or other analysis-driven phenomena. } \\
\text { - Description of sampling technique, }{ }^{27} \text { including whether the sample has changed and developed over } \\
\text { the course of your study. }{ }^{11} \\
\text { - Flexible participant recruitment and setting to maximize participation (e.g., choose locations that make } \\
\text { participants feel welcome). }{ }^{30}\end{array}$ \\
\hline Data collection technique & $\begin{array}{l}\text { - Clear articulation of data collection strategies. }{ }^{27,29} \\
\text { - Appropriate data collection methods for the research objectives and setting (three main subtypes are } \\
\text { mentioned - field observation, interviews, document analysis) }{ }^{18,30} \text { : } \\
\text { o Focus groups - not substitute for one-to-one interviews or a survey. Useful for what participants } \\
\text { think, but even better at uncovering why participants think as they do. } \\
\text { - Comprehensive data collection to support rich and robust descriptions of the observed/experienced } \\
\text { events or phenomena. }{ }^{18} \\
\text { - Use of piloting collection tools - piloting your scripts (e.g., for focus groups) ensures rigour of our } \\
\text { questioning technique. }\end{array}$ \\
\hline $\begin{array}{l}\text { Data interpretation \& theory } \\
\text { generation }\end{array}$ & $\begin{array}{l}\text { - Systematic data analysis }{ }^{11,28} \text { that aligns with analytic processes with known methods to ensure: } \\
\circ \text { Appropriate reduction and displaying of the collected data - identifying key categories and } \\
\text { representing these appropriately. }{ }^{11} \\
\text { - Conclusions are drawn from analysis category clusters. }{ }^{11} \\
\text { - Linkages made between the findings of the study and other existing theories OR development of new } \\
\text { theory relevant to targeted field/discipline. }{ }^{27} \\
\text { - Evaluation of observations and theorems }{ }^{31} \text { or theory development }{ }^{27,31} \text { when appropriately given the } \\
\text { selected analytic technique (e.g., grounded theory). }\end{array}$ \\
\hline $\begin{array}{l}\text { Measures to optimize rigour \& } \\
\text { trustworthiness }\end{array}$ & $\begin{array}{l}\text { - Data analysis uses methods that establish trustworthiness throughout the study, }{ }^{28,29} \text { detailing methods } \\
\text { that adequately corroborate }{ }^{18} \text { or confirm }{ }^{30} \text { the investigator's findings. } \\
\text { - Use of reflexivity }{ }^{28,11} \text { by investigators, specifically: } \\
\text { - Clear statement of the effect on the data of the researcher's views and the methods chosen that } \\
\text { have been included. }{ }^{27} \\
\text { o Explicit evaluation of the relationship between the researcher and those under research, addressing } \\
\text { any ethical issues. }{ }^{27} \\
\text { - Using one or more of the following techniques to increase rigour of the analysis: }{ }^{11} \\
\text { - Saturation }{ }^{11} \\
\text { - Triangulation }{ }^{11,28}\end{array}$ \\
\hline
\end{tabular}




\begin{tabular}{|c|c|}
\hline Category & Item \\
\hline \multirow{9}{*}{ Relevance to the field } & o Respondent feedback ("member checking") ${ }^{11}$ \\
\hline & - Fair dealing ${ }^{11}$ \\
\hline & $\begin{array}{l}\text { - If multiple methods are in used to increase the rigour of the work, clear description of each method, } \\
\text { including their benefit - e.g., source triangulation, allows to examine the issue from multiple types of } \\
\text { data collection. }{ }^{11}\end{array}$ \\
\hline & - Significant results. ${ }^{25}$ \\
\hline & - Assessment of transferability to other similar environments. ${ }^{27,31}$ \\
\hline & - Practical, useful implications. ${ }^{26}$ \\
\hline & - Comprehensive and relevant theoretical conclusions. ${ }^{19}$ \\
\hline & - Evocative and thorough description of results. ${ }^{19}$ \\
\hline & - Insight into context of medical practice..$^{19}$ \\
\hline \multirow[t]{3}{*}{ Dissemination \& reporting } & - Effective presentation. ${ }^{25}$ \\
\hline & - Well-written manuscript (clear, straightforward, easy to follow, logical). ${ }^{26}$ \\
\hline & - Clear explanation of technical language - e.g., explaining terms such as saturation. ${ }^{11}$ \\
\hline Evidence of reflective practice & $\begin{array}{l}\text { - Reflective critique }{ }^{25} \text { of one's own study, particularly evaluating other findings in similar contexts to } \\
\text { examine whether the results are easily transferable across settings. }{ }^{27} \\
\text { - Account of the limitations of the study. }{ }^{26}\end{array}$ \\
\hline
\end{tabular}

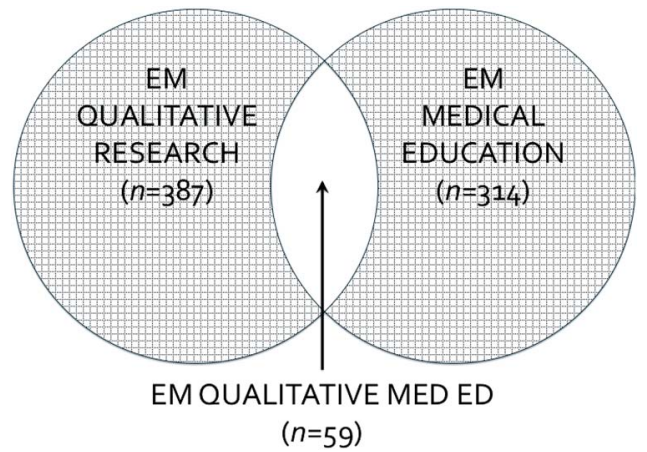

Figure 2. Number of emergency medicine, qualitative and medical education papers in our literature search.

checklists described in Table 3. Some of the items that we found were broader in their scope (i.e., more general guidance) around important aspects to consider when writing a qualitative paper. As such, we feel that the list generated by our present scoping review may help augment the advice presented by the previous literature, because it aggregates the wisdom reported in papers that may not have been used to inform the creation of previous checklists (e.g., the SRQR). ${ }^{32}$

There are, however, a number of challenges and barriers to using qualitative research. ${ }^{17}$ For instance, researchers using these techniques must be tolerant of ambiguity and be comfortable in presenting nonnumerical data. Also, unlike quantitative studies, researchers must be intimately involved in the generation and interpretation of data. ${ }^{6}$ Swaths of work cannot simply be outsourced to a junior collaborator or a hired statistician. Finally, regardless of the type of medical education scholarship, novice educators may find it difficult to get their research published, whether they are engaged in qualitative methods or not. ${ }^{33}$

This scoping review and adjunctive analyses provide resources that may be useful to educators in designing, implementing, and writing up qualitative research. Attention to quality indicators and awareness of available checklists and publication venues may help educators overcome common obstacles to publication, and increase interest and engagement in qualitative research.

\section{LIMITATIONS}

This paper provides a literature-informed review of existing guides for conducting and authoring qualitative research in EM. Although it cannot replace formal methodological training and mentoring, it may serve as a complementary resource that can scaffold early career and new qualitative scientists when writing within medical education. Although efforts were made to systematically search the literature, it is possible that relevant publications could have been missed, especially because our search was restricted to the Englishlanguage only. In addition, inclusion processes and thematic analyses do involve researcher involvement in 


\begin{tabular}{|c|c|}
\hline Citation & Content \\
\hline $\begin{array}{l}\text { Côté } L \text {, Turgeon J. Appraising qualitative } \\
\text { research articles in medicine and } \\
\text { medical education. Med Teach 2005;27 } \\
\text { (1):71-5. }\end{array}$ & $\begin{array}{l}\text { - Provides a simple grid of } 12 \text { points. } \\
\text { - Points are grouped under headings: } \\
\text { - Introduction, Methods, Results, Discussion, Conclusion. } \\
\text { - Three ranking options: Yes, No, or }+/- \text {. } \\
\text { - For each point there is: a) an explanation, b) an example, and c) suggestions for further } \\
\text { reading. } \\
\text { - Useful for clinical teachers when appraising qualitative research and teaching appraisal skills. }\end{array}$ \\
\hline $\begin{array}{l}\text { Hanson JL, Balmer DF, Giardino AP. } \\
\text { Qualitative research methods for } \\
\text { medical educators. Acad Peds } \\
\text { 2011;11:375-86. }\end{array}$ & $\begin{array}{l}\text { - Provides a checklist of criteria for the "trustworthiness and validity" of qualitative research. } \\
\text { - Includes an appendix that can be used as a worksheet for developing a qualitative project. } \\
\text { - Checklist is grouped under the headings: credibility (internal validity), transferability (external } \\
\text { validity), dependability (reliability), and confirmability (objectivity). } \\
\text { - No scoring is involved, just concepts to consider. } \\
\text { The paper notes: "planning rigorous qualitative research requires prospective attention to the } \\
\text { articulation of research questions, data collection strategies, a sampling plan, and data analysis } \\
\text { methods, with attention to methods that establish trustworthiness throughout the study."29 }\end{array}$ \\
\hline $\begin{array}{l}\text { Farrell SE, Kuhn GJ, Coates WC, et al. } \\
\text { Critical appraisal of emergency medicine } \\
\text { education research: The best } \\
\text { publications of 2013. Acad Emerg Med } \\
\text { 2014;21(11):1274-83. }\end{array}$ & $\begin{array}{l}\text { - Outlines a complex Research Scoring Metric to identify papers that are methodologically superior. } \\
\text { Provided in a table of this paper. }\end{array}$ \\
\hline $\begin{array}{l}\text { O'Brien BC, Harris IB, Beckman TJ, et al. } \\
\text { Standards for reporting qualitative } \\
\text { research: a synthesis of } \\
\text { recommendations. Acad Med 2014;89 } \\
\text { (9):1245-51. }\end{array}$ & $\begin{array}{l}\text { - Developed } 21 \text { reporting standards: Standards for Reporting Qualitative Research (SRQR). } \\
\text { - Reviewed all criteria found in a search of peer-reviewed and grey, Web-based sources; then } \\
\text { iteratively modified and coded the items, to arrive at a consensus. } \\
\text { - Provides a useful list to consult when considering a project, preparing and editing manuscripts, } \\
\text { for editorial review of manuscripts for publication, and for critical appraisal by the consumer. } \\
\text { - Developed a detailed list of "features of quality." }\end{array}$ \\
\hline $\begin{array}{l}\text { Redefining quality in medical education } \\
\text { research: a consumer's view. } \\
J \text { Grad Med Educ } \\
\text { 2014;6(3):424-9. }\end{array}$ & $\begin{array}{l}\text { - Nine additional pithy Quick Quality Questions }\left(\mathrm{Q}^{3}\right) \text {. } \\
\text { - Grouped under headings: Title/lntro, Methods, Results, Writing, Visuals \& Access. } \\
\text { - Use of Proceedings of } 2013 \text { AAMC consensus workshop to determine what criteria of } \\
\text { medical education research are most highly valued by consumers. } \\
\text { - N.B., Does not specifically pertain to qualitative research per se, but is nonetheless useful in } \\
\text { determining quality and value. }\end{array}$ \\
\hline
\end{tabular}

the data, and it is possible that saturation was not reached, either of the relevant papers, or of the quality markers.

Table 4. List of journals with at least two citations of qualitative research in emergency medicine medical education, listed in alphabetical order

- Academic Emergency Medicine*

( ${ }^{*}$ Has a new sister journal, AEM Education \& Training, that focuses exclusively on EM education and training)

- Academic Medicine

- Annals of Emergency Medicine

- British Medical Journal Open

- Canadian Journal of Emergency Medicine

- Emergency Medicine Australasia

- Emergency Medicine Journal

- Journal of Emergency Medicine

- Journal of Graduate Medical Education

\section{CONCLUSIONS}

There are many papers to guide early education researchers towards reporting and conducting high quality qualitative research. We have reported 39 quality markers that should be considered when authoring qualitative medical education studies, which we have grouped into 10 key categories. Additionally, we present five previously published quality checklists, which will assist authors in preparing qualitative manuscripts for publication. Our paper may serve as a primer for early career educators who aim to enhance the rigour of their qualitative educational research.

Competing interests: None declared. 


\section{REFERENCES}

1. Bergman E, de Feijter J, Frambach J, et al. AM last page: a guide to research paradigms relevant to medical education. Acad Med 2012;87(4):545, doi:10.1097/ACM.0b013e31824fbc8a.

2. Boet S, Sharma S, Goldman J, et al. Medical education research: an overview of methods. Can 7 Anesth 2012;59:159-70, doi:10.1007/s12630-011-9635-y.

3. Tavakol M, Sandars J. Quantitative and qualitative methods in medical education research: AMEE guide no 90: part II. Med Teach 2014;36(10):838-48, doi:10.3109/0142159X.2014.915297.

4. McKinley RK. Qualitative and quantitative: the yin and the yang or the light and the dark sides of medical education? Perspect Med Educ 2015;4(1):1-3, doi:10.1007/s40037-015-0162-3.

5. Sullivan GM, Sargeant J. Qualities of qualitative research: part I. 7 Grad Med Educ 2011;3(4):449-52, doi:10.4300/JGME-D-11-00221.1.

6. Sargeant J. Qualitative research part II: participants, analysis, and quality assurance. 7 Grad Med Educ 2012;4(1):1-3, doi:10.4300/JGME-D-11-00307.1.

7. Teherani A, Martimianakis T, Stenfors-Hayes T, et al. Choosing a qualitative research approach. 7 Grad Med Educ 2015;7(4):669-70, doi:10.4300/JGME-D-15-00414.1.

8. Compton S, Lang E, Richardson TM, et al. Knowledge translation consensus conference: research methods. Acad Emerg Med 2007;14(11):991-5, doi:10.1197/j.aem.2007.06.031.

9. Farrell SE, Kuhn GJ, Coates WC, et al. Critical appraisal of emergency medicine education research: the best publications of 2013. Acad Emerg Med 2014;21(11):1274-83, doi:10.1111/acem.12507.

10. Yarris LM, Juve AM, Coates WC, et al. Critical appraisal of emergency medicine education research: the best publications of 2014. Acad Emerg Med 2015;22(11):1327-36, doi:10.1111/acem.12801.

11. Cooper S, Endacott R. Generic qualitative research: a design for qualitative research in emergency care? Emerg Med 7 2007;24(12):816-9, doi:10.1136/emj.2007.050641.

12. Turner TL, Balmer DF, Coverdale JH. Methodologies and study designs relevant to medical education research. Int Rev Psychiatry 2013;25(3):301-10, doi:10.3109/09540261. 2013.790310

13. Lingard L, Albert M, Levinson W. Grounded theory, mixed methods, and action research. BM7 2008;337:459-61, doi:10.1136/bmj.39602.690162.47.

14. Farrell L, Bourgeois-Law G, Regehr G, et al. Autoethnography: introducing "I" into medical education research. Med Educ 2015;49(10):974-82, doi:10.1111/medu.12761.

15. Genn JM, Harden RM. What is medical education here really like? Suggestions for action research studies of climates of medical education environments. Med Teach 1986;8(2):111-24.

16. Schifferdecker KE, Reed VA. Using mixed methods research in medical education: basic guidelines for researchers. Med Educ 2009;43(7):637-44, doi:10.1111/j.1365-2923.2009.03386.x.

17. Ziebland S, McPherson A. Making sense of qualitative data analysis: an introduction with illustrations from DIPEx (personal experiences of health and illness). Med Educ 2006;40(5):405-14, doi:10.1111/j.1365-2929.2006.02467.x.

18. Giacomini MK, Cook DJ. Users' guides to the medical literature: XXIII. Qualitative research in health care A. Are the results of the study valid? $7 \mathrm{Am}$ Med Assoc 2000; 284(3):357-62.

19. Giacomini MK, Cook DJ. Users' guides to the medical literature XXIII. Qualitative research in health care B. What are the results and how do they help me care for my patients? FAMA 2000;284(4):478-82.

20. Arskey H, O'Malley L. Scoping studies: towards a methodological framework. Int 7 Soc Res Methodol 2004; $8(1): 19-32$.

21. Gehanno J, Rollin L, Darmoni S. Is the coverage of Google Scholar enough to be used alone for systematic reviews? BMC Med Inform Decis Mak 2013;13(1):1, doi:10.5210/ ojphi.v5i2.4623.

22. Paterson QS, Thoma B, Milne WK, et al. A systematic review and qualitative analysis to determine quality indicators for health professions education blogs and podcasts. 7 Grad Med Ed 2015;7(4):549-54.

23. Chan TM, Wallner C, Swoboda TK, et al. Assessing interpersonal and communication skills in emergency medicine. Acad Emerg Med 2012;19(12):1390-402, doi:10.1111/acem.12030.

24. Sebok SS. Understanding how raters communicate in the context of medical high-stakes, performance-based assessments; 2015. Available at: http://qspace.library.queensu. ca/jspui/bitstream/1974/13713/1/Sebok_Stefanie_S_201509_ PhD.pdf.

25. Glassick CE. Boyer's expanded definitions of scholarship, the standards of assessing scholarship, and the elusiveness of the scholarship of teaching. Acad Med 2000; 75(9):877-80.

26. Bordage G. Reasons reviewers reject and accept manuscripts: the strengths and weaknesses in medical education reports. Acad Med 2001;76(9):889.

27. Kitto S. Quality in qualitative research. Med 7 Aust 2007; 188(4):243-6, doi:10.4135/9781848608191.

28. Stacy R, Spencer J. Assessing the evidence in qualitative medical education research. Med Educ 2000;34(7): 498-500.

29. Hanson JL, Balmer DF, Giardino AP. Qualitative research methods for medical educators. Acad Pediatr 2006;11(5): 375-86, doi:10.1016/j.acap.2011.05.001.

30. Barbour RS. Making sense of focus groups. Med Educ 2005;39(7):742-50, doi:10.1111/j.1365-2929.2005.02200.x.

31. Binder LS, Chapman DM. Qualitative research methodologies in emergency medicine. Acad Emerg Med 1995; 2(12):1098-102.

32. O'Brien BC, Harris IB, Beckman TJ, et al. Standards for reporting qualitative research. Acad Med 2014;89(9): 1245-51, doi:10.1097/ACM.0000000000000388.

33. Norman G. How bad is medical education research anyway? Adv Heal Sci Educ 2007;12(1):1-5, doi:10.1007/s10459-0069047-x. 